\title{
Cloning and Characterization of Pyridoxal Kinase from Geobacillus sp. $\mathrm{H6a}$
}

\author{
Jumnong Pasri, Chamaiporn Champasri (iD) and Yanee Trongpanich* (iD \\ Department of Biochemistry, Faculty of Science, Khon Kaen University, Khon Kaen, 40002, Thailand .
}

\begin{abstract}
Pyridoxal kinase encoded by $p d x K$ gene, is the important key enzyme in the salvage pathway of vitamin $B_{6}$ biosynthesis. The enzyme catalyzes the phosphorylation of the 5 ' alcohol groups of free form vitamin $B_{6}$ into their 5 '-phosphate forms that requires metal ion and ATP. Pyridoxal kinase have been reported in many organisms except in the thermophilic bacterium. Therefore, this study aimed to clone, express and characterize pyridoxal kinase of Geobacillus sp. $\mathrm{H6a}$ isolated from the hot spring in the North of Thailand. The GhpdxK gene ( 810 base pairs) was inserted into pET28a(+) plasmids at restriction site of $\mathrm{Ndel}$ and $\mathrm{BamHI}$ and transformed into E.coli BL21(DE3). The expressed pyridoxal kinase of this bacterium exhibits a homodimer, in which each subunit had a molecular mass of about $32 \mathrm{kDa}$ when examined by SDS-PAGE and gel filtration. The enzyme showed maximal activity at $70^{\circ} \mathrm{C}$ and at $\mathrm{pH} 8.0$. The expressed enzyme obtained in this study was found to be more active $(>50 \%)$ in the broad pH range $(6.0-9.0)$ than those previously reported. This enzyme prefers $\mathrm{Mg}^{2+}$ and also accepts other cations to the less extent. Under optimal conditions, the expressed enzyme has higher affinity toward PN $(20 \pm 1.35 \mu \mathrm{M})$, while it showed the same affinity to pyridoxal $(100 \pm 0.76 \mu \mathrm{M})$ and pyridoxamine $(100 \pm 1.21 \mu \mathrm{M})$. The $K_{\mathrm{m}}$ value for ATP and 4-amino-5-hydroxymethyl-2-methylpyridine were $8.99 \pm 1.76 \mu \mathrm{M}$ and $19 \pm 0.85$ $\mu \mathrm{M}$, respectively. With high activity at high temperature and active in the broad $\mathrm{pH}$ range, it could be considered as a potential candidate for future application particularly bioconversion of vitamin $B_{6}$.
\end{abstract}

Keywords: pyridoxal kinase, salvage, thermophile, vitamin $B_{6}$

\footnotetext{
*Correspondence: yantro@kku.ac.th

(Received: June 8, 2021; accepted: January 4, 2022)

Citation: Pasri J, Champasri C, Trongpanich Y. Cloning and Characterization of Pyridoxal Kinase from Geobacillus sp. H6a. J Pure Appl Microbiol. 2022;16(1):365-373. doi: 10.22207/JPAM.16.1.30

(C) The Author(s) 2022. Open Access. This article is distributed under the terms of the Creative Commons Attribution 4.0 International License which permits unrestricted use, sharing, distribution, and reproduction in any medium, provided you give appropriate credit to the original author(s) and the source, provide a link to the Creative Commons license, and indicate if changes were made.
} 


\section{INTRODUCTION}

Vitamin $B_{6}$ is a group of pyridine derivative related vitamers, including pyridoxal $(\mathrm{PL})$, pyridoxine $(\mathrm{PN})$, pyridoxamine $(\mathrm{PM})$, and their 5'-phosphorylated forms. Among the $B_{6}$ group, pyridoxal 5'-phosphate (PLP) and pyridoxamine 5'-phosphate (PMP) are the most important coenzymes, involved in various biochemical reactions, including the metabolisms of amino acids, carbohydrates, fatty acids, lipids, nucleic acids, hemoglobin, serotonin, dopamine, noradrenaline, and gamma-aminobutyric acid (GABA) neurotransmitters. ${ }^{1}$

Eukaryotes obtain vitamin $B_{6}$ from food. Microorganisms and plants can newly synthesize vitamin $\mathrm{B}_{6}$ by using a deoxyxylulose $5^{\prime}$-phosphate (DXP)-dependent pathway or a DXP-independent pathway, while a salvage pathway is found in most organisms. A role of salvage pathway is to interconvert the six different forms of vitamin $\mathrm{B}_{6}$ by using four enzymes. Pyridoxal kinase (PLK; EC 2.7.1.35) phosphorylates the $5^{\prime}$-alcohol groups of all three unphosphorylated $B_{6}$ vitamers into their phosphate forms. Pyridoxine 5'-phosphate oxidase (PNPO; EC 1.4.3.5) catalyzes the oxidation of PMP and PNP to PLP. Dephosphorylation of PNP, PMP and PLP is catalyzed by phosphatase. The reduction of $\mathrm{PL}$ to $\mathrm{PN}$ is catalyzed by $\mathrm{PL}$ reductase (EC 1.1.1.65). ${ }^{2,3}$

Pyridoxal kinase belongs to the ribokinase superfamily. It transfers a phosphate group at $\gamma$ position of ATP to the C5 position of free form vitamin $\mathrm{B}_{6}$ in a metal (mono and divalent cations)-dependent manner. Besides PN, PL and PM, PLK can catalyze the mono-phosphorylation of 4-amino-5-hydroxymethyl-2-methylpyridine (HMP) involving thiamine biosynthesis. ${ }^{4}$ This enzyme has been found in various sources. PLK is encoded by 2 kinase genes. A basic kinase gene $(p d x K)$ has found in eukaryotes and prokaryotes. The other ( $p d x y)$ found in Escherichia coli, is able to phosphorylate only PL as substrate. ${ }^{2,5}$

Pyridoxal kinase from the $p d x K$ gene is a homodimer. Molecular mass of each monomer has approximately $35.4 \mathrm{kDa}$. The amino acid sequence of mammal PLK is highly conserved with $>80 \%$ identity, while that of PLKs showed approximately $40 \%$ identity in the group of microorganisms, plants, and mammals. ${ }^{6}$ Bioinformatics assays showed the comparison between Leishmania infantum PLK and Trypanosoma protein sequence had a low similarity, with identity percentage of $61.04-66.11 \% .^{7}$ These data indicate PLK has high variation.

Pyridoxal kinase has been purified and characterized from Arabidopsis thaliana,${ }^{8}$ human, ${ }^{9}$ Bacillus subtilis, ${ }^{10}$ Plasmodia falciparum, ${ }^{11}$ E. coli, ${ }^{12}$ Bombyx mori, ${ }^{13}$ Trypanosoma brucei, ${ }^{14}$ Pseudomonas aeruginosa, ${ }^{5}$ Salmonella typhimurium, ${ }^{15}$ however, purification and characterization of PLK from thermophilic bacteria have not been reported.

Our previous study showed that Geobacillus sp.H6a (Gh) could produce vitamin $\mathrm{B}_{6}$ outside the cell. ${ }^{16}$ This thermophilic bacterium grows at a range of temperature of $30-70^{\circ} \mathrm{C}$ with the highest growth rate at $60^{\circ} \mathrm{C}$. The objectives of this study were to clone, express the $p d x K$ gene in E. coli and characterize the recombinant PLK of Geobacillus sp.H6a.

\section{MATERIALS AND METHODS Materials}

A Genomic DNA mini kit, High-Speed Plasmid Mini Kit and a Gel/PCR DNA fragment extraction kit were purchased from Geneaid Biotech Ltd. (Taipei, Taiwan). A Taq DNA Polymerase was purchased from RBC Bioscience (Taipei, Taiwan). A Ni-nitrilotriacetic acid (NTA) resin column was purchased from Novagen, UK. A Superdex 200 and Vivaspin ${ }^{\circledR} 20$ were purchased from GE Healthcare Bio-Science AB (Sweden). All others were of analytical grade chemicals.

\section{Cloning of GhpdxK gene}

The genomic DNA of Geobacillus sp. H6a was isolated by Genomic DNA mini kit. The primers FpdxKNde (5'-AAACATATGATGCCAA AAGCGTTAACGATCGCC -3') with a Ndel recognition site (underlined) and 3pdxKBam (5'-AAAGGATCCTTATTTGTTCGCCGTAGCGG-3')17 with a BamHI recognition site (underlined) were used to amplify GhpdxK gene (accession number FJ497251). Amplification was operated in a thermal-cycler as follows: 30 cycles of $1 \mathrm{~min}$ at $95^{\circ} \mathrm{C}, 1 \mathrm{~min}$ at $62^{\circ} \mathrm{C}, 2 \mathrm{~min}$ at $72^{\circ} \mathrm{C}$ and final $10 \mathrm{~min}$ at $72^{\circ} \mathrm{C}$. The annealing temperature was decreased by $2^{\circ} \mathrm{C}$ per cycle until $58^{\circ} \mathrm{C}$. The PCR product was checked by agarose gel electrophoresis and was subsequently purified before digestion with $\mathrm{Ndel}$ and BamHI. 
The pET28a(+) vector was isolated using High-Speed Plasmid Mini Kit and subsequently digested with the same restriction enzymes. The resulting digested PCR product and the digested pET28a(+) vector were purified by using a Gel/PCR DNA fragment extraction kit and were ligates by using T4 ligase enzyme. The resulted constructs designated as pET28a-GhpdxK was transformed into E. coli BL21(DE3) by using heat shock method. Colony PCR was used to check the transformants. DNA sequencing was carried out by First Base Laboratories (Malaysia).

Expression optimization of recombinant GhPLK (rGhPLK)

The bacterial cells harboring pET-28aGhpdxK were cultured in Luria - Bertani (LB) medium with $50 \mu \mathrm{g} \mathrm{ml}-1$ kanamycin, until the absorbance at $600 \mathrm{~nm}$ of the culture increased to 0.5 . The expression of rGhPLK was induced by adding different concentrations of isopropyl1-thio-D-galactopyranoside (IPTG) $(0-1 \mathrm{mM})$, different incubation temperatures $\left(25^{\circ} \mathrm{C}, 30^{\circ} \mathrm{C}\right.$, $\left.37^{\circ} \mathrm{C}\right)$ and times $(0,1,3,6 \mathrm{~h})$.

The cells were collected by centrifugation at $10,000 \times \mathrm{g}, 4^{\circ} \mathrm{C}$ for $10 \mathrm{~min}$. The cell pellet was resuspended in $5 \mathrm{ml}$ of ice-cold $1 x$ phosphate buffer saline (PBS), $\mathrm{pH} 7.4$, containing $1 \mathrm{mM}$ phenylmethylsulfonyl fluoride (PMSF). The suspension was lysed by ultrasonication and the resulting cell lysate was centrifuged at $15,000 \times \mathrm{g}$ for $10 \mathrm{~min}$ at $4^{\circ} \mathrm{C}$. Protein concentration was determined by the Bradford assay, ${ }_{1}^{18}$ using bovine serum albumin as a standard protein.

\section{Purification of recombinant GhPLK}

The rGhPLK protein was purified by Ninitrilotriacetic acid (NTA) resin column which was equilibrated with $20 \mathrm{mM}$ potassium phosphate buffer (KPB) pH 8.0, containing $0.5 \mathrm{M} \mathrm{NaCl}, 10 \%$ glycerol, $1 \mathrm{mM}$ 2-mercaptoethanol (2-ME) and 10 $\mathrm{mM}$ imidazole and collected at $1 \mathrm{ml}$ per fraction at flow rate of $0.25 \mathrm{ml} / \mathrm{min}$. The column was washed with $20 \mathrm{mM} \mathrm{KPB} \mathrm{pH} \mathrm{8.0,} \mathrm{containing} 0.5 \mathrm{M} \mathrm{NaCl}$, $10 \%$ glycerol, $1 \mathrm{mM} 2-\mathrm{ME}$ and $90 \mathrm{mM}$ imidazole until absorbance at $280 \mathrm{~nm}$ was less than 0.1 . The rGhPLK protein was eluted with the same buffer, containing $500 \mathrm{mM}$ imidazole. The fractions were tested activity and determined absorbance at $280 \mathrm{~nm}$. The eluted fractions displaying enzyme activities, were pooled for dialysis against $20 \mathrm{mM}$
$\mathrm{KPB} \mathrm{pH} 8.0$, containing $10 \%$ glycerol and $1 \mathrm{mM}$ 2-ME. The dialysis protein was concentrated by Vivaspin ${ }^{\circledR}$ with $10 \mathrm{kDa}$ cutoff and was subjected further analysis.

\section{Enzyme assay of recombinant GhPLK}

The rGhPLK activity was measured following to the method of Huang ${ }^{13}$ with some modifications. The assay activity was performed at $70^{\circ} \mathrm{C}$. The reaction mixture of $1 \mathrm{ml}$ contained $70 \mathrm{mM}$ KPB pH 8.0, $0.4 \mathrm{mM}$ PL, $3 \mathrm{mM}$ ATP, $10 \mathrm{mM}$ $\mathrm{MgCl}$. The assay activity was started by adding $0.3 \mu \mathrm{g}$ purified rGhPLK and then the reaction was incubated for $30 \mathrm{~min}$. PLP concentration was determined by monitoring the absorbance at 388 $\mathrm{nm}\left(\varepsilon 388=4900 \mathrm{M}^{-1} \mathrm{~cm}^{-1}\right.$ in phosphate buffer, $\mathrm{pH}$ 7.0) comparing with a standard curve of different concentrations of PLP standard against A388. One unit of enzyme was described as the amount of the enzyme required to produce $1 \mu \mathrm{mol}$ of PLP per min.

To study the effect of $\mathrm{pH}$, temperature and metal ions, the formed product (PLP) in enzyme reaction mixture using $\mathrm{PL}$ as a substrate was counted using the method of Wada and Snell. ${ }^{19}$ The reaction mixture contained $70 \mathrm{mM} \mathrm{KPB}$ $\mathrm{pH}$ 8.0, $0.4 \mathrm{mM} \mathrm{PL}, 3 \mathrm{mM}$ ATP, $10 \mathrm{mM} \mathrm{MgCl}, 0.3$ $\mu \mathrm{g}$ purified $\mathrm{rGhPLK}$ and then incubated for $30 \mathrm{~min}$ at $70^{\circ} \mathrm{C}$. A $8 \%$ trichloroacetic acid (TCA) was added and the reaction was leaved on-ice for $10 \mathrm{~min}$. The centrifugation was then performed at $10,000 \times \mathrm{g}$ for $1 \mathrm{~min}$. The supernatant was added with $0.1 \%$ phenylhydrazine reagent and left for $10 \mathrm{~min}$ at room temperature. The concentration of PLP was determined by an increase of an absorbance at 410 $\mathrm{nm}$ which was compared to that of PLP standard $(0-400 \mathrm{nmol})$.

To study kinetic, the activity of purified rGhPLK was performed using a pyruvate kinase - lactate dehydrogenase coupled system. ${ }^{10}$ The reaction mixture contained $70 \mathrm{mM} \mathrm{KPB} \mathrm{pH} \mathrm{8.0,}$ $0.4 \mathrm{mM} \mathrm{PL}, 3 \mathrm{mM}$ ATP, $10 \mathrm{mM} \mathrm{MgCl}$, and $0.3 \mu \mathrm{g}$ purified $\mathrm{rGhPLK}$. The reaction was incubated at $70^{\circ} \mathrm{C}$ for $30 \mathrm{~min}$, then stored on ice. One $\mathrm{mM}$ of phosphoenolpyruvate, $0.2 \mathrm{mM}$ of $\mathrm{NADH}, 8$ units of each pyruvate kinase and lactate dehydrogenase were added in the previous reaction. The reaction was then incubated at $37^{\circ} \mathrm{C}$ for $10 \mathrm{~min}$. The activity was determined by measuring the decrease in absorbance at $340 \mathrm{~nm}$ resulted from the oxidation 
of $\mathrm{NADH}$. One unit of activity means the oxidation of $1 \mu \mathrm{mol}$ of $\mathrm{NADH}$ per min using an extinction coefficient for NADH (A $340=6220 \mathrm{M}^{-1} \mathrm{~cm}^{-1}$ ) to determine rate of ADP production.

\section{Molecular mass determination}

The molecular mass and the purity of the rGhPLK protein were determined by using $12 \%$ SDS-PAGE. ${ }^{20}$ Both SDS-PAGE and NativePAGE were stained with Coomassie Brilliant Blue $\mathrm{R}-250$. The native form of recombinant enzyme was determined by using gel filtration column $(1 \times 30 \mathrm{~cm}$ ) manually packed with Superdex 200 . The gel filtration standards (Bio-Rad) composes of thyroglobulin (670 kDa), $\gamma$-globulin (158 kDa), ovalbumin (44 kDa), myoglobin (17 kDa), and Vitamin B12 (1.35 kDa) were also loaded on the column and were used for determination of the molecular weight of rGhPLK. ${ }^{21}$

\section{Kinetic of recombinant GhpdxK}

The enzyme kinetic $\left(\mathrm{K}_{\mathrm{m}}\right.$ and $\left.\mathrm{V}_{\max }\right)$ were determined by incubating the purified rGhPLK with varying concentrations of substrates. The data were calculated by using GraphPad Prism software version 6.01 (GraphPad software, Inc). ${ }^{21}$

\section{Effects of $\mathrm{pH}$ and temperature}

The activity of rGhPLK was studied in $\mathrm{pH}$ range $3.0-10.0$ with $70 \mathrm{mM}$ of each buffer: $\mathrm{pH} 3.0$ glycine- $\mathrm{HCl}$ buffer; $\mathrm{pH} 4.0$ - 5.0 acetate buffer; pH 6.0 phosphate buffer; pH $7.0-8.0$ HEPES buffer; pH 9.0 Tris-HCl buffer; pH 10.0 glycine- $\mathrm{NaOH}$ buffer. For $\mathrm{pH}$ stability, $\mathrm{rGhPLK}$ was incubated in different $\mathrm{pH}$ for $1 \mathrm{~h}$ at $30^{\circ} \mathrm{C}$ then measured activity by phenylhydrazine method. ${ }^{19}$ Effect of temperature was studied at $25-80^{\circ} \mathrm{C}$ with $70 \mathrm{mM} \mathrm{KPB} \mathrm{pH} \mathrm{8.0.} \mathrm{For} \mathrm{temperature} \mathrm{stability,}$ rGhPLK was incubated in different temperatures $\left(30-80^{\circ} \mathrm{C}\right)$ and then the activity was measured by using phenylhydrazine method. ${ }^{19}$

\section{Effects of metal ions}

Metal ions effect was assayed using a variety of monovalent and divalent cations $\left(\mathrm{Cs}^{+}\right.$, $\mathrm{Zn}^{2+}, \mathrm{Ca}^{2+}, \mathrm{Mg}^{2+}, \mathrm{Mn}^{2+}, \mathrm{Cu}^{2+}, \mathrm{Ni}^{2+}$ and $\left.\mathrm{Fe}^{2+}\right)$ in $20 \mathrm{mM}$
$\mathrm{KPB} \mathrm{pH} 8.0$ at $70^{\circ} \mathrm{C}$. The enzymatic activity was assayed with $0.6,3$, and $6 \mathrm{mM}$ of each metal ions. The relative percentage activity was calculated on the basis of the measured activity in the highest activity of metal ion. ${ }^{21}$

\section{RESULTS AND DISCUSSION}

Cloning and expression of recombinant GhPLK

The PCR product of $p d x K$ gene from Geobacillus sp.H6a was 810 base pairs (Fig. 1). Its open reading frame (ORF) encoded 269 amino acids with a predicted molecular weight of 29.06 $\mathrm{kDa}$ and theoretical isoelectric point of 5.56. ${ }^{17}$ The expression of rGhPLK was not found in an uninduced crude extract. The low expression of rGhPLK was found upon induction with $1 \mathrm{mM}$

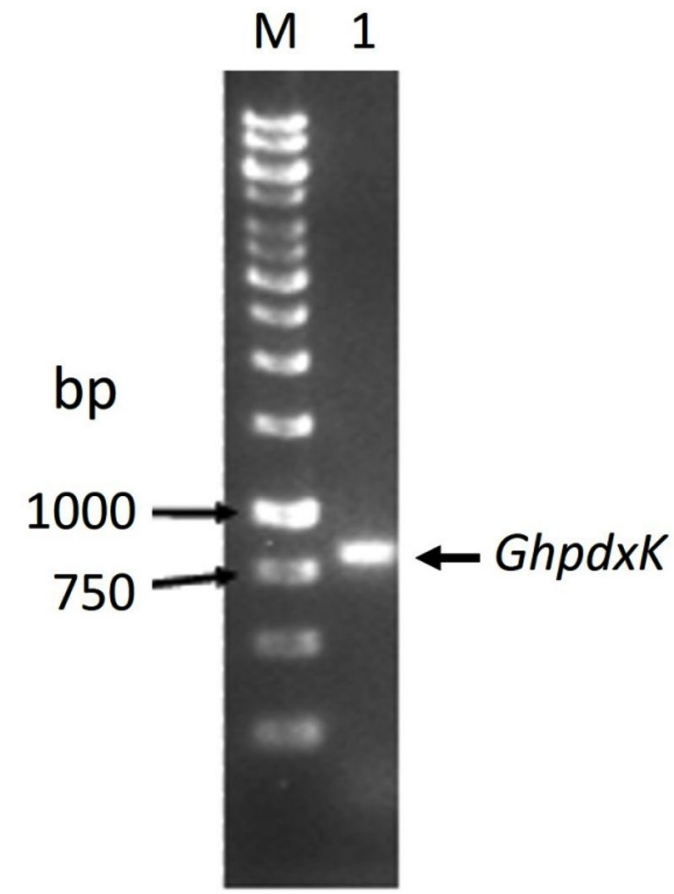

Fig. 1. Electrophoresis of the PCR product of $p d x K$ gene from Geobacillus sp.H6a. Lane M is 1 kb DNA Ladder marker (Thermo Fisher Scientific); Lane 1 is GhpdxK gene.

Table 1. Purification of recombinant GhPLK produced by E. coli BL21 (DE3)

\begin{tabular}{lccccc}
\hline Fraction & $\begin{array}{c}\text { Total Protein } \\
\text { (mg) }\end{array}$ & $\begin{array}{c}\text { Total activity } \\
(\mathrm{mmol} / \mathrm{min})\end{array}$ & $\begin{array}{c}\text { Specific Activity } \\
(\mathrm{mmol} / \mathrm{min} / \mathrm{mg})\end{array}$ & $\begin{array}{c}\text { Purification } \\
(\text { fold })\end{array}$ & $\begin{array}{c}\text { Yield } \\
(\%)\end{array}$ \\
\hline Crude extract & 378.9 & 3276.9 & 8.65 & 1.00 & 100 \\
Ni-NTA affinity & 39.48 & 498.4 & 12.62 & 1.46 & 15.21 \\
\hline Journal of Pure and Applied Microbiology & & 368 & & www.microbiologyjournal.org
\end{tabular}


IPTG at $37^{\circ} \mathrm{C}$. In order to increase the rGhPLK expression level in crude extract, different induction temperatures of 25 and $30^{\circ} \mathrm{C}$, and IPTG concentrations of $0-1 \mathrm{mM}$, and induction time (1, 3 and $6 \mathrm{~h}$ ) were examined. The result showed that using $0.5 \mathrm{mM}$ IPTG with an induction time of $6 \mathrm{~h}$ at $30^{\circ} \mathrm{C}$ was the optimum condition to increase activity of crude rGhPLK (Fig. 2).

\section{Purification of recombinant GhPLK}

The rGhPLK contained N-terminal hexahistidine tag sequence, was purified from crude lysates by using Ni NTA column. The profile of purification was shown in Table 1. In Fig. 3a, SDSPAGE showed single band of approximately $32 \mathrm{kDa}$ in molecular weight. Molecular weight of single subunit of rGhPLK was similar to PLK reported

\section{KDa}

Uninduced

\section{IPTG Induced}

\section{$\begin{array}{lllllllll}0 & 1 & 3 & 6 & M & 0 & 1 & 3 & 6\end{array}$}

\section{7}

66

\section{5}

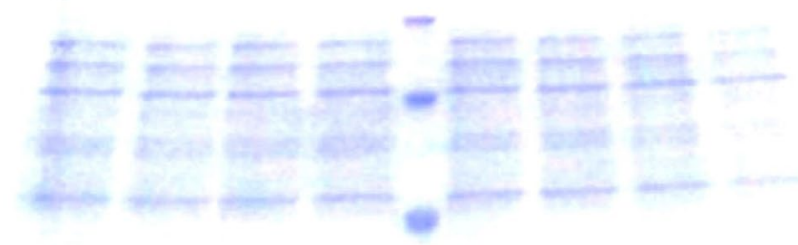

30

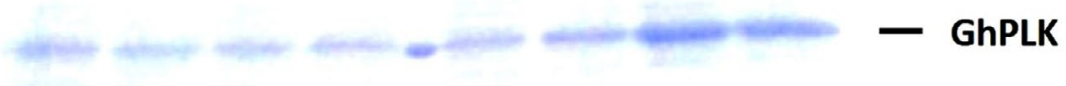

\section{5}

Fig. 2. SDS-PAGE (12\%) analysis of GhpdxK expression in E. coli BL21(DE3). Total proteins of BL21 (DE3) harboring pET-28a-GhpdxK induced by $0.5 \mathrm{mM} \mathrm{IPTG}$ at $30^{\circ} \mathrm{C}$ for $0,1,3$ and $6 \mathrm{~h}$ and uninduced fractions at different time point were included as a control.

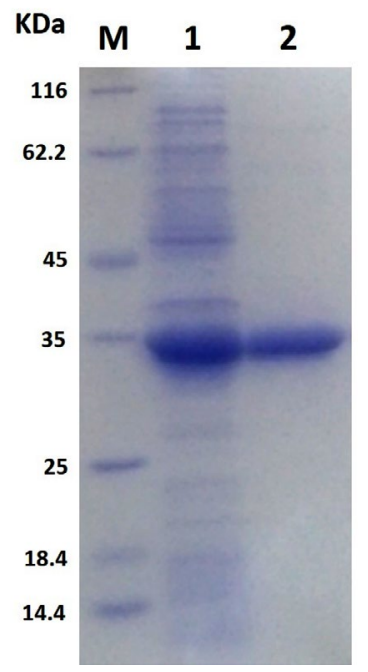

Fig. 3. Analysis of the purification of rGhPLK by SDSPAGE (12\%) and Native PAGE (6\%). (a) Lane M is protein molecular weight marker (Thermo Fisher Scientific); Lane 1 is crude extract of $E$. coli BL21 (DE3) harboring pET-28a-GhpdxK; Lane 2 is purified rGhPLK. (b) Native PAGE of purified rGhPLK. from other organisms: $35 \mathrm{kDa}$ from E. coli, ${ }^{22} 37$ $\mathrm{kDa}$ from T. brucei, ${ }^{23} 35 \mathrm{kDa}$ from $A$. thaliana, ${ }^{8}$ and $33.9 \mathrm{kDa}$ from $B$. mori, ${ }^{13}$ The rGhPLK showed single band on Native PAGE (Fig. 3b), while gel filtration showed single peak of rGhPLK with molecular weight calculated approximately of $60 \mathrm{kDa}$ (Fig. 4). These data suggested that the rGhPLK was a dimer with two identical subunits, which was the same as other PLKs. ${ }^{5,8,13,15,22,23}$

\section{Effects of $\mathrm{pH}$ and temperature}

The activity of $\mathrm{rGhPLK}$ was found in a $\mathrm{pH}$ range of $4-10$. It gradually increased at a $\mathrm{pH}$ range of $3-8$ and showed the highest activity at $\mathrm{pH} 8.0$ (Fig. 5a). The rGhPLK was found to be active in the broad $\mathrm{pH}$ range when compared with PLK from $A$. thaliana, ${ }^{8}$ S. typhimurium ${ }^{15}$ and B. mori ${ }^{13}$ which had activities in the narrow $\mathrm{pH}$ range of $5.5-7.5$, $6.2-6.6$ and $5.5-6.0$, respectively. The stability of rGhPLK between $\mathrm{pH} 3$ and 10 was showed in Fig. $5 \mathrm{~b}$. The rGhPLK was stable ( $>70 \%$ activity) between $\mathrm{pH} 8$ and 9 , and its activity extremely lost at a pH range of $3-7$ after incubation for $1 \mathrm{~h}$ at $30^{\circ} \mathrm{C}$. 
The rGhPLK has an optimal temperature at $70^{\circ} \mathrm{C}$ (Fig. $5 \mathrm{C}$ ). For temperature stability, the enzyme activity was decreased when the time was increased (Fig. $5 \mathrm{~d}$ ). It retained $>50 \%$ activity after storage at $30^{\circ} \mathrm{C}-70^{\circ} \mathrm{C}$ for $30 \mathrm{~min}$ and at $30^{\circ} \mathrm{C}-$ $40^{\circ} \mathrm{C}$ for $60 \mathrm{~min}$. The loss of activity at $30-70^{\circ} \mathrm{C}$ is somewhat strikingly because $\mathrm{G}$. $\mathrm{H} 6$ a could grow at a range of temperature of $30-70^{\circ} \mathrm{C}$ and the optimal growth temperature is $60^{\circ} \mathrm{C}^{16}$ It is possible that the enzyme is not in the desire environment as it is present in a cell. Recombinant expression might affect folding of enzyme structure and influence the stability of enzyme.

\section{Effects of metal ions}

Both mono and divalent cations are involved the function of PLK. Fig. 6 showed the effect of metal ions on the rGhPLK activity using three concentrations of $0.6,3$ and $6 \mathrm{mM}$. The highest activity was found when used $6 \mathrm{mM}$ of $\mathrm{Mg}^{2+}$. The activity of rGhPLK was increased when increased the concentrations of $\mathrm{Mg}^{2+}$ and $\mathrm{Ni}^{2+}$ from $0.6 \mathrm{mM}$ to $6 \mathrm{mM}$. While $\mathrm{Cs}^{+}, \mathrm{Zn}^{2+}$ and $\mathrm{Cu}^{2+}$

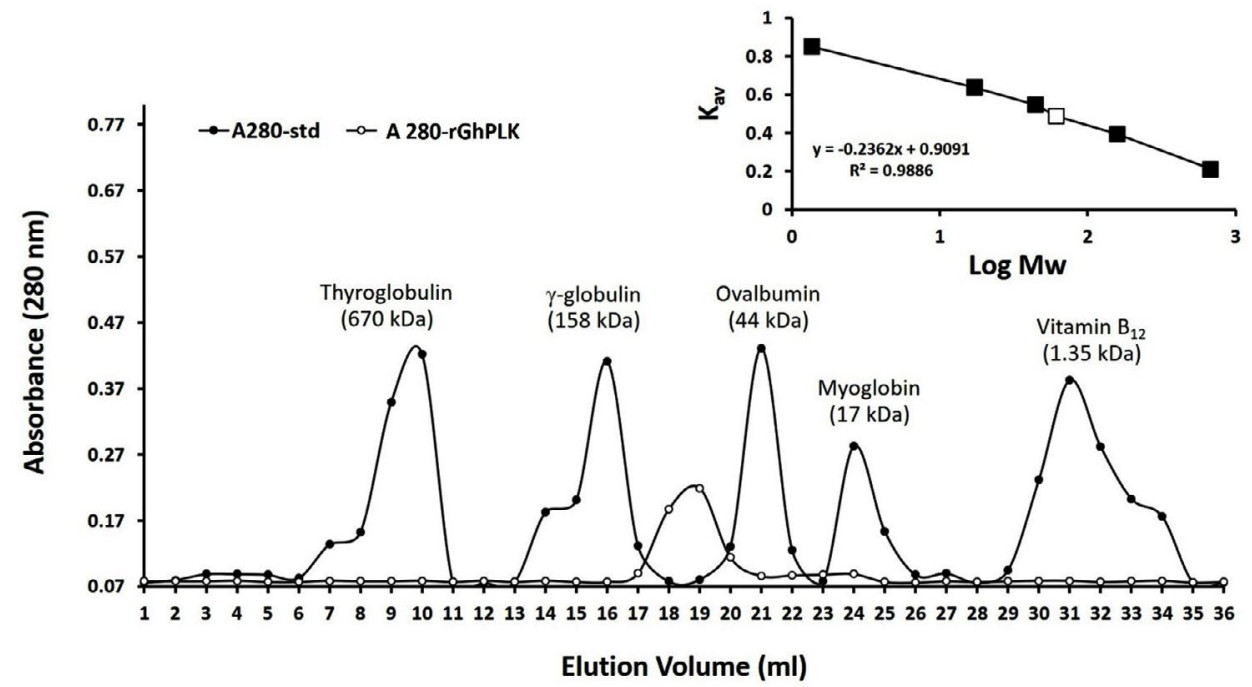

Fig. 4. Gel filtration chromatography of recombinant GhPLK. Inset, Kav of peaks of standard (black square) and peak rGhPLK (white square) in logarithmic scale.

a

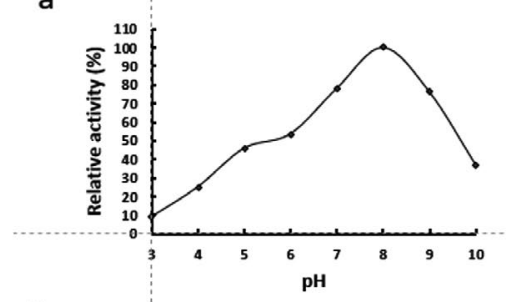

C

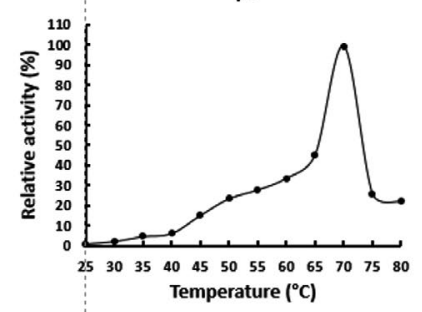

b

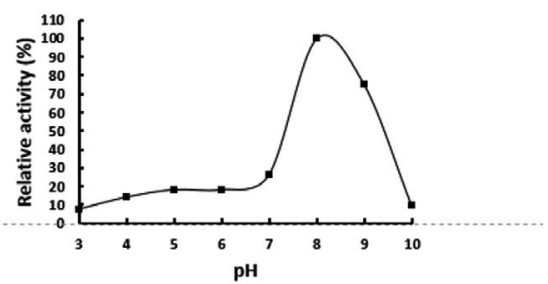

d

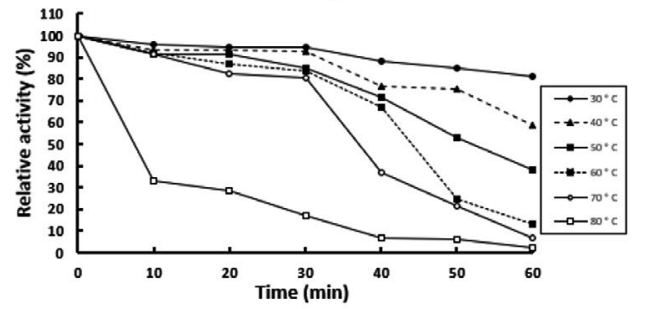

Fig. 5. Effects of temperature and pH on activity and stability of the recombinant GhPLK. (a) pH optimum (b) pH stability (c)Temperature optimum (d) Thermal stability. 
showed decrease of the activity when increasing concentration of the metals. $\mathrm{Mn}^{2+}$ and $\mathrm{Fe}^{2+}$ had positive effect on the enzyme activity at $3 \mathrm{mM}$ concentration. While $\mathrm{Ca}^{2+}$ had little effect to the activity of rGhPLK. Navarro et al..$^{24}$ observed that the effect of metal ion on the activity of PLK is highly dependent on the relative concentrations of metal and nucleotide used. Our results obviously showed this effect when $\mathrm{Fe}^{2+}$ was at equimolar concentrations with the ATP concentration ( 3 $\mathrm{mM})$. However, the effect of $\mathrm{Fe}^{2+}$ on the enzyme activity at $3 \mathrm{mM}$ still less than that of $\mathrm{Mg}^{2+}$ at $6 \mathrm{mM}$ concentration. $\mathrm{Mg}^{2+}$ has found to be the preferred divalent ion in PLK from S. typhimurium ${ }^{15}$ and $E$. coli ${ }^{9}$ under physiological conditions in cells. While PLK from other organisms prefers $\mathrm{Zn}^{2+}$ such as $\mathrm{B}$. mori, ${ }^{13} A$. thaliana ${ }^{8}$ and human. ${ }^{24}$

\section{Kinetic of recombinant GhpdxK}

The $\mathrm{K}_{\mathrm{m}}$ and $\mathrm{V}_{\text {max }}$ values were examined by incubating the rGhPLK with varying concentrations of substrates, which explained by MichaelisMenten plots (Fig. 7). Among vitamin $\mathrm{B}_{6}$ substrates (PL, PN and PM), rGhPLK has higher affinity toward PN $(20 \mu \mathrm{M})$, while it showed the same affinity (100 $\mu M)$ to $P L$ and PM. These data show the affinity to vitamin $B_{6}$ substrates similar with PLK from human (PN, $20 \mu \mathrm{M}$; PL, $30 \mu \mathrm{M}$; PM, $35 \mu \mathrm{M}$ ) and E. coli ${ }^{9}$ (PN, $25 \mu \mathrm{M}$; PL, $100 \mu \mathrm{M}$; PM, $30 \mu \mathrm{M}$ ). However,

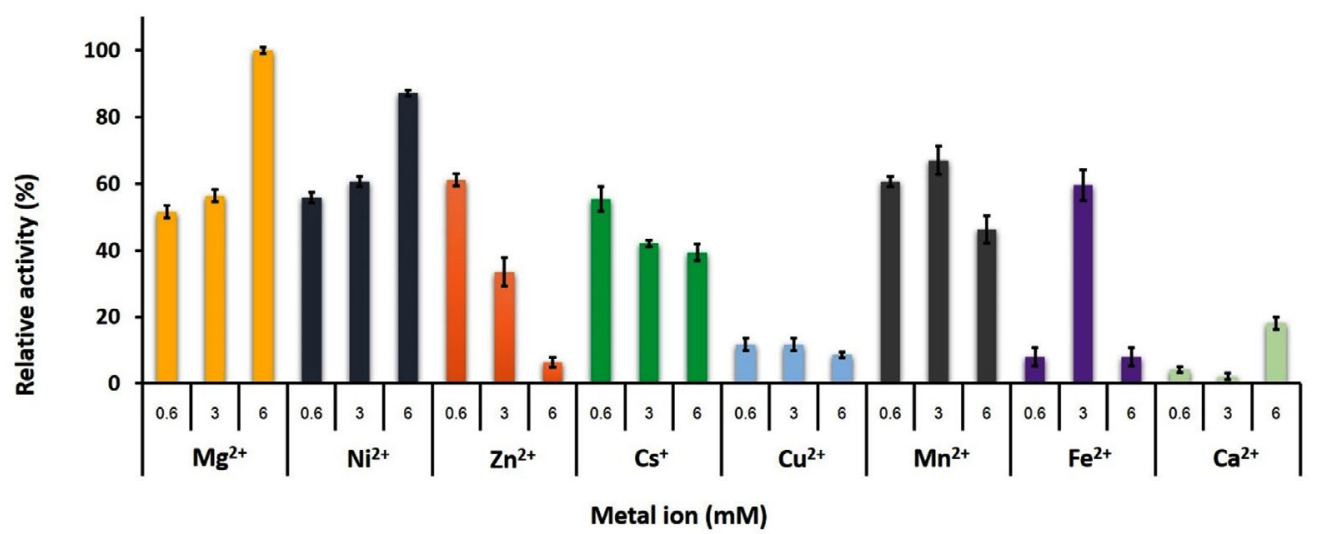

Fig. 6. Effects of metal ions on the activity of recombinant GhPLK. The assay mixture contained $20 \mathrm{mM} \mathrm{KPB}$ at $\mathrm{pH}$ $8,0.4 \mathrm{mM} \mathrm{PL}, 3 \mathrm{mM}$ ATP and $0.3 \mu \mathrm{g}$ of rGhPLK. Assays were performed in triplicate.
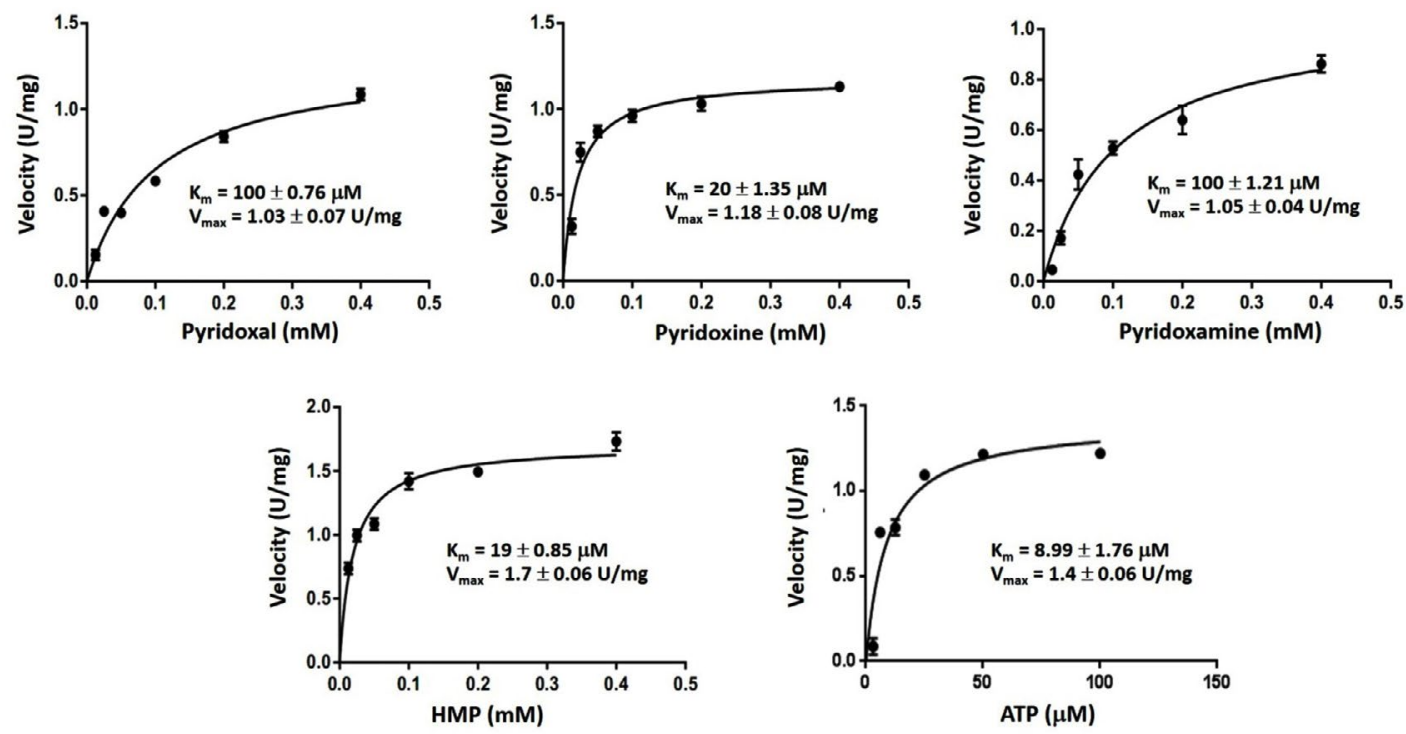

Fig. 7. Kinetic study of rGhPLK. 
the $\mathrm{Km}$ value for PL of rGhPLK is about 2 times lower than that of the enzyme of $B$. subtilis ${ }^{10}(46.6$ $\mu \mathrm{M})$, B. mori $^{13}(44.1 \mu \mathrm{M})$ and S. typhimurium ${ }^{15}(44$ $\mu M)$. The $K_{m}$ value of rGhPLK for ATP was $8.99 \mu \mathrm{M}$, which is about 10 times higher than the $\mathrm{K}_{\mathrm{m}}$ value reported for $S$. typhimurium ${ }^{15}(100 \mu \mathrm{M})$ and $P$. aeruginosa $a^{5}(102 \mu \mathrm{M})$. The $\mathrm{K}_{\mathrm{m}}$ value for HMP (19 $\mu \mathrm{M}$ ) was higher than those determined for the $B$. $\operatorname{subtilis}^{10}(2,030 \mu \mathrm{M})$ and S. aureus ${ }^{25}(1,988 \mu \mathrm{M})$.

\section{CONCLUSION}

This is the first report describing the characterization of PLK from thermophilic bacterium. The rGhPLK is a dimer with two identical subunits $(32 \mathrm{kDa})$. The enzyme can phosphorylate all $\mathrm{B}_{6}$ vitamers (PN, PM, PL) and HMP. The preferred substrate is PN. The rGhPLK prefers $\mathrm{Mg}^{2+}$ and also accepts other cations to the less extent. The rGhPLK had optimum temperature at $70^{\circ} \mathrm{C}$, and found to be active in the broad $\mathrm{pH}$ range. It could be considered as a potential candidate for future application particularly bioconversion of vitamin $\mathrm{B}_{6}$. Future research will be focused on development of a more effective thermal stability and activity of this enzyme.

\section{ACKNOWLEDGMENTS}

None.

\section{CONFLICT OF INTEREST}

The authors declare that there is no conflict of interest.

\section{AUTHORS' CONTRIBUTION}

YT designed and directed the project. JP performed the experiments. CC and YT wrote the manuscript. All authors read and approved the final manuscript for publication.

\section{FUNDING}

This work was granted by Khon Kaen University (Grant No. 540025) Research Fund, and Khon Kaen University under the Incubation Researcher Project, Khon Kaen University, Thailand.

\section{DATA AVAILABILITY}

All datasets generated or analyzed during this study are included in the manuscript.

\section{ETHICS STATEMENT}

This article does not contain any studies with human participants or animals performed by any of the authors.

\section{REFERENCES}

1. Shtyrlin YG, Petukhov AS, Strelnik AD, et al. Chemistry of Pyridoxine in Drug Design. Russ Chem Bull. 2019;68(5):911-945. doi: 10.1007/s11172-019-2504-5

2. di Salvo ML, Contestabile R, Safo MK. Vitamin $B_{6}$ Salvage Enzymes: Mechanism, Structure and Regulation. Biochim Biophys Acta BBA - Proteins Proteomics. 2011;1814(11):1597-1608. doi: 10.1016/j. bbapap.2010.12.006

3. Ramos RJ, Albersen M, Vringer E, et al. Discovery of Pyridoxal Reductase Activity as part of Human Vitamin $B_{6}$ Metabolism. Biochim Biophys Acta BBA Gen Subj. 2019;1863(6):1088-1097. doi: 10.1016/j. bbagen.2019.03.019

4. Cea PA, Araya G, Vallejos G, et al. Characterization of Hydroxymethylpyrimidine Phosphate Kinase from Mesophilic and Thermophilic Bacteria and Structural Insights into their Differential Thermal Stability. Arch Biochem Biophys. 2020;688:108389. doi: 10.1016/j. abb.2020.108389

5. Kim MI, Hong M. Crystal Structure and Catalytic Mechanism of Pyridoxal Kinase from Pseudomonas aeruginosa. Biochem Biophys Res Commun. 2016;478(1):300-306. doi: 10.1016/j.bbrc.2016.07.007

6. Shi R, Zhang J, Jiang C, Huang L. Bombyx mori Pyridoxal Kinase cDNA Cloning and Enzymatic Characterization. J Genet Genomics. 2007;34(8):683-690. doi: 10.1016/ S1673-8527(07)60077-0

7. Oliveira-da-Silva JA, Machado AS, Ramos FF, et al. Evaluation of Leishmania infantum Pyridoxal Kinase Protein for the Diagnosis of Human and Canine Visceral Leishmaniasis. Immunol Lett. 2020;220:11-20. doi: 10.1016/j.imlet.2020.01.005

8. Lum HK, Kwok F, Lo S. Cloning and Characterization of Arabidopsis thaliana Pyridoxal Kinase. Planta. 2002;215(5):870-879. doi: 10.1007/s00425-002-07990

9. di Salvo ML, Hunt S, Schirch V. Expression, Purification, and Kinetic Constants for Human and Escherichia coli Pyridoxal Kinases. Protein Expr Purif. 2004;36(2):300306. doi: 10.1016/j.pep.2004.04.021

10. Park JH, Burns K, Kinsland C, Begley TP. Characterization of Two Kinases Involved in Thiamine Pyrophosphate and Pyridoxal Phosphate Biosynthesis in Bacillus subtilis: 4-Amino-5-Hydroxymethyl-2-Methylpyrimidine Kinase and Pyridoxal Kinase. J Bacteriol. 2004;186(5):15711573. doi: 10.1128/JB.186.5.1571-1573.2004

11. Wrenger C, Eschbach ML, Muller IB, Warnecke D, Walter RD. Analysis of the Vitamin $\mathrm{B}_{6}$ Biosynthesis Pathway in the Human Malaria Parasite Plasmodium falciparum. J Biol Chem. 2005;280(7):5242-5248. doi: 10.1074/jbc.M412475200

12. Safo MK, Musayev FN, di Salvo ML, Hunt S, Claude JB, Schirch V. Crystal Structure of Pyridoxal Kinase from the Escherichia coli pdxK Gene: Implications for 
the Classification of Pyridoxal Kinases. J Bacteriol. 2006;188(12):4542-4552. doi: 10.1128/JB.00122-06

13. Huang $\mathrm{SH}, \mathrm{Ma} \mathrm{W}$, Zhang PP, Zhang JY, Xie YF, Huang LQ. Recombinant Expression, Purification and Characterization of Bombyx mori (Lepidoptera: Bombycidae) Pyridoxal Kinase. Eur J Entomol. 2011;108(1):25-34. doi: 10.14411/eje.2011.003

14. Jones DC, Alphey MS, Wyllie S, Fairlamb AH. Chemical, Genetic and Structural Assessment of Pyridoxal Kinase as a Drug Target in the African Trypanosome. $\mathrm{Mol}$ Microbiol. 2012;86(1):51-64. doi: 10.1111/j.13652958.2012.08189.x

15. Deka G, Kalyani JN, Jahangir FB, Sabharwal P, Savithri HS, Murthy MRN. Structural and Functional Studies on Salmonella typhimurium Pyridoxal Kinase: the First Structural Evidence for the Formation of Schiff Base with the Substrate. FEBS J. 2019;286(18):3684-3700. doi: 10.1111/febs.14933

16. Anutrakunchai $C$, Niamsanit S, P. Wangsomnuk P, Trongpanich $Y$. Isolation and Characterization of Vitamin B $_{6}$-Producing Thermophilic Bacterium, Geobacillus sp. H6a. J Gen Appl Microbiol. 2010;56(3):273-279. doi: 10.2323/jgam.56.273

17. Waithayawanthiti C, Anutakunchai C, Trongpanich Y. Bioinformatics and Expression Analysis of Pyridoxal Kinase in Vitamin B-6-Producing Thermophilic Bacterium, Geobacillus sp. H6a. KKU Sci J. 2020;48(3):307-317.

18. Bradford MM. A Rapid and Sensitive Method for the Quantitation of Microgram Quantities of Protein Utilizing the Principle of Protein-Dye Binding. Anal Biochem. 1976;72(1-2):248-254. doi: 10.1016/00032697(76)90527-3
19. Wada H, Snell EE. The Enzymatic Oxidation of Pyridoxine and Pyridoxamine Phosphates. I Biol Chem. 1961;236(7):2089-2095. doi: 10.1016/S00219258(18)64134-1

20. Manns JM. SDS-Polyacrylamide Gel Electrophoresis (SDS-PAGE) of Proteins. Curr Protoc Microbiol. 2011;22(1):A.3M.1-A.3M.13. doi: 10.1002/9780471729259.mca03ms22

21. Sinthusiri A, Champasri C, Trongpanich Y. Recombinant Expression Purification and Characterization of Pyridoxal 5'-phosphate Synthase from Geobacillus sp. H6a Thermophilic Bacterium Producing Extracellular Vitamin B . Iran J Biotechnol. 2021;19(4):70-82. doi: 10.30498/ijb.2021.201202.2575

22. White RS, Dempsey WB. Purification and Properties of Vitamin $B_{6}$ Kinase from Escherichia coli B. Biochemistry. 1970;9(21):4057-4064. doi: 10.1021/bi00823a005

23. Scott TC, Phillips MA. Characterization of Trypanosoma brucei Pyridoxal Kinase: Purification, Gene Isolation and Expression in Escherichia coli. Mol Biochem Parasitol. 1997;88(1-2):1-11. doi: 10.1016/S01666851(97)00077-7

24. Navarro F, Ramirez-Sarmiento CA, Guixe V. Catalytic and Regulatory Roles of Species Involved in MetalNucleotide Equilibriums in Human Pyridoxal Kinase. Bio Metals. 2013;26(5):805-812. doi: 10.1007/s10534013-9660-0

25. Nodwell MB, Koch MF, Alte F, Schneider S, Sieber SA. A Subfamily of Bacterial Ribokinases Utilizes a Hemithioacetal for Pyridoxal Phosphate Salvage. J Am Chem Soc. 2014;136(13):4992-4999. doi: 10.1021/ ja411785r 